\title{
UMKM GO ONLINE! PENGEMBANGAN KOMPETENSI PELAKU USAHA MIKRO KECIL MENENGAH (UMKM) DI PROVINSI DKI JAKARTA GUNA MEWUJUDKAN DIGITAL PRENEUER
}

\author{
Hania Aminah', Dewi Susita² ${ }^{2}$ Hamidah $^{3}$ \\ Fakultas Ekonomi, Universitas Negeri Jakarta \\ Jl. Rawamamgun Muka Jakarta Timur \\ Email Korespendensi: hania@unj.ac.id
}

\begin{abstract}
ABSTRAK
Tujuan dari kegiatan ini adalah untuk mengembangkan dan meningkatkan kompetensi yang harus dimiliki oleh para pelaku UMKM melalui pelatihan Soft Skills, jiwa kewirausahaan dan pemahaman kewirausahaan digital. Pengembangan dan peningkatan yang dilakukan berupa pengembangan keterampilan soft skills, jiwa kewirausahaan, dan pemahaman kewirausahaan digital sehingga dapat berguna dalam mengembangkan usaha yang akan dijalankan di kemudian hari.Guna mewujudkan program pemerintah untuk menjadikan Usaha Mikro Kecil Menengah (UMKM) yang Go Online! Serta mendukung langkah pemerintah Indonesia dalam menghadapi era Industri 4.0, maka hampir seluruh sektor yang ada berupaya untuk mewujudkan hal tersebut. Salah satu sektornya adalah sektor Industri, dimana perkembangan teknologi yang begitu pesat mengharuskan seluruh elemen industri untuk transfromasi menggunakan Artificial Intelligence. Pelaku Usaha Mikro Kecil Menengah (UMKM) merupakan salah satu pelaku industri yang sangat perlu diperhatikan yag dapat disebut juga dengan genrasi digital, untuk itu upaya menyatukan antara generasi muda, teknologi, dan industri 4.0, makan diperlukan pelaksanaan pelatihan guna meningkatkan keterampilan-keterampilan yang dibutuhkan. Kajian dilakukan dengan menggunakan metode survey dengan penyebaran kuesioner.
\end{abstract}

Kata Kunci: UMKM Go Online, Digital, Kompetensi.

\begin{abstract}
The purpose of this activity is to develop and improve the competencies that must be possessed by MSME players through Soft Skills training, entrepreneurial spirit and understanding of digital entrepreneurship. The development and enhancement carried out is in the form of developing soft skills, entrepreneurial spirit, and understanding digital entrepreneurship so that it can be useful in developing businesses that will be run in the future. In order to realize government programs to make Micro, Small and Medium Enterprises (MSMEs) Go Online! As well as supporting the steps of the Indonesian government in facing the Industrial 4.0 era, almost all existing sectors are trying to make this happen. One sector is the Industrial sector, where the rapid development of technology requires all industrial elements to be transformed using Artificial Intelligence. Micro, Small and Medium Enterprises (MSMEs) are one of the industry players who really need to pay attention to what can be called digital generation, for that an effort to unite the young generation, technology, and industry 4.0, it is necessary to carry out training to improve the skills needed. The study was conducted using a survey method with distributing questionnaires.
\end{abstract}

Keywords: SME Go Online, Digital, Competence 


\section{PENDAHULUAN}

Masuknya era industry baru yakni program pemerintah UMKM Go Online di Indonesia mulai tahun 2017 membuat Pemerintah Indonesia perlu melakukan gerakan cepat untuk dapat menangkap peluang tersebut sebagai langkah untuk terus dapat bersaing dan berkolaborasi secara global. Menurut Kementerian Perindustrian terdapat empat strategi Indonesia untuk masuk kedalam revolusi industry keempat, yang pertama adalah mendorong angkatan kerja untuk meningkatkan keterampilan terutama dalam penggunaan internet of things, yang kedua pemanfaatan teknologi digital untuk mendorong produktivitas dan daya saing bagi industry kecil dan menengah (IKM) untuk menembus ekspor, yang ketiga adalah penggunaan digital technology, serta yang keempat adalah inovasi teknologi.

Keempat strategi tersebut merupakan acuan untuk mengambil langkah-langkah selanjutnya agar strategi dapat tercapai. Inisiatif dari kementerian Perindustrian tersebut mampu menjadi pedoman bagi stakeholder yang terkait untuk bias meningkatkan kompetensi sumber daya manusia menuju competitive advantage.

Berdasarkan peringkat daya saing (Global Competitiveness Index) hasil rilis dari World Economic Forum (WEF) Indonesia untuk periode tahun 2016-2017 berada di peringkat 41 turun 4 peringkat dari periode tahun sebelumnya, adapun pada periode tahun 2017-2018 Indonesia naik peringkat ke 36 namun masih di bawah Singapura dan Malaysia hal tersebut menjadi tugas berat bagi pemerintah untuk lebih perhatian terhadap daya saing Bangsa Indonesia, tentu dengan menggandeng seluruh elemen dan pemangku kepentingan yang terkait. Dimana salah satu yang dapat menjadi sumbangsih terhadap daya saing adalah dengan meningkatkan sumber daya manusianya.

Salah satu upaya untuk meningkatkan sumber daya manusia adalah melalui investasi Pendidikan dimana pendidikan masih dan akan terus menjadi pondasi utama dan akan seterusnya sesuai dengan undang-undang pemerintah Indonesia yakni pemerataan pendidikan secara Nasional, namun pada dasarnya tidak hanya sekedar pemerataan pendidikan akan tetapi juga berdasar kepada kualitas sumber daya manusinya (SDM). Kualitas SDM dapat dilihat dari kompetensinya, dimana kompetensi pada dasarnya sudah ada sejak manusia dilahirkan, namun perlu diasah dan ditingkatkan lebih dalam agar kompetensi seseorang dapat berfungsi dengan baik sesuai dengan kebutuhannya.

Sehingga berdasarkan kebutuhan dari Pemerintah Indonesia guna untuk mengembangkan dan meningkatkan daya saing SDM Indonesia, maka lulusan dari perguruan tinggi dan sekolah kejuruan merupakan lulusan yang penting untuk diperhatikan kelanjutan masa depannya, yang juga dapat membantu mengurangi tingkat pengangguran di Indonesia, dimana saat ini menurut Badan Pusat Statistik (BPS) tingkat pengangguran Indonesia per bulan Agustus tahun 2017 sebesar 5,50 persen, yang sebenarnya sudah turun dari tahun lalu sebesar 5,61 persen. Tingkat pengangguran tersebut dapat menjadi polemic baru bagi program pemerintah UMKM Go Online, seperti yang dijelaskan di awal bahwa program pemerintah UMKM Go Online merupakan industry baru bagiBangsa Indonesia yang harus segera diantisipasi dengan peningkatanpeningkatan sejumlah kompetensi agar dapat bersaing di dunia inudstri khususnya terutama dengan menciptakan lapangan-lapangan kerja agar dapat membantu pemerintah dalam mengatasi masalah pengangguran.

Hal tersebut juga disampaikan oleh Samora, bahwa revolusi program pemerintah UMKM Go Online dapat menjadi ancaman pengangguran massal di masa depan, dimana kehadiran mesin dan teknologi yang begitu cepat mengharuskan SDM-SDM di Indonesia 
untuk meningkatkan keterampilannya dan jangan sampai terdisrupsi oleh digital dan robot. Oleh karena itu para pelaku UMKM memiliki peranan yang sangat penting agar dapat bersaing di dunia industri. Sehingga saat ini yang menjadi salah satu fokus penulis adalah pada para pelaku UMKM dapat mennjadi wirausaha dengan menciptakan lapangan pekerjaan dengan pemanfaatan digital platform. Menjadi pekerja dan wirausaha tentu tidaklah mudah, diperlukan berbagai keahlian dan keterampilan serta tekad dan semangat yang kuat untuk mewujudkannya.

Untuk itu isu besar yang dijelaskan di atas menjadi perhatian khusus bagi tim penyusun proposal untuk mengmbangkan nya melalui sebuah pendekatan yaitu pelatihan dan pendampingan. Karenanya, tim penyusun proposal ini mempunyai ide untuk membuat pengabdian kepada masyarakat dengan judul " UMKM Go Online! Pengembangan Kompetensi Pelaku UMKM di Provinsi DKI Jakarta Guna Mewujudkan Digital Preneur".

\section{Peranan Kewirausahaan dan Usaha Kecil dan Menengah (UKM) pada Perekonomian Nasional}

Tercatat kontribusi usaha kecil di beberapa Negara maju seperti halnya di Amerika Sertikat yang mampu menyerap tenaga kerja sampai dengan 58\% dan 40\% GDP hasil dari sumbangan usaha kecil, namun hal tersebut juga tidak hanya di Negara maju tetapi juga di Negara berkembang yang memiliki peran yang cukup tinggi dalam kontribusi yang positif terhadap penanggulangan masalah-masalah ekonomi dan sosial, berupa tingginya tingkat kemiskinan, besarnya jumlah pengangguran, ketimpangan distribusi pendapatan, dan lainnya.

Sehingga diaktakan oleh Lupiyoadi dalam Agustina (2015:6) bahwa dampak sosioekonomi dari adanya wirausaha, adalah:

1. Menciptakan lapangan kerja;

2. Meningkatkan kualitas hidup;

3. Meningkatkan pemerataan pendapatan;

4. Memanfaatkan dan memobilisasi sumber daya untuk meningkatkan produktivitas Nasional;

5. Meningkatkan kesejahteraan pemerintah melalui program pemerintahan seperti pajak.

Pertumbuhan angkatan kerja di dalam sebuah organisasi formal maupun informal berkembang pesat, hal tersebut juga seiring dengan semakin besarnya gap yang terjadi diantara angakatan kerja, dimana perbedaan mendasarnya adalah masalah usia, baik termasuk kelompok tua maupun yang muda, dijelaskan oleh Ozcelik (2015) bahwa generasi didefinisikan sebagai kelompok yang saling berbagi satau sama lain dalam usia yang berbeda sehingga kelompok dengan berbeda usia merupakan sebuah generasi yang nantinya dapat disebut dengan beda generasi. Hal-hal yang menjadi perbedaan generasi atau kelompk pada dasarnya tidak hanya sebatas usia, namun juga nilai-nilai yang dianut, pandangan hidup, budaya, pengalaman dalam sudut pandang ekonomi dan politik, termasuk dalam kelompok yang berbeda atau generasi yang berbeda, hal tersebut juga diperkuat oleh (Ozcelik:2015). Senada dengan penjelasan dari S.W.Ng et al (2010) yang menyatakan bahwa generasi dapat dilihat juga dari ketertarikannya, tantangan dalam bekerja, dan bagaimana kontribusi yang akan diberikan. Dengan demikian generasi 
merupakan sebuah kelompok yang memiliki beragam perbedaan yang dilihat dari berbagai sudut pandang yang berbeda.

Perbedaan generasi yang dijelaskan termasuk dalam lingkup yang cukup luas, dimana salah satu perbedaan yang dapat dilihat adalah dari usia, yang merupakan salah satu generasi yang saat ini mendapat perhatian khusus adalah yang disebut dengan generasi milenial. Menurut Karl Mannheim dalam Adam yang dutulis di Tirto (2018) generasi milenial adalah kelompok yang dibedakan berdasarkan usia dengan kategori tahun kelahiran 1980-an sampai dengan 1997, mereka adalah kelompok yang pernah melewati millennium kedua, yakni mereka yang lahir pada tahun-tahun tersebut yang pada saat ini berada pada kisaran usia 20-30 tahun. Adapun menurut Smola dan Sutton (2002) dalam Myers dan Sadaghiani bahwa generasi milenial adalah mereka yang lahir pada tahun antara 1974 dan 1994 atau yang popular dengan istilah generasi "look at me". Sebuah generasi yang memiliki kepercayaan diri yang tinggi serta daya serap yang tinggi yang dapat bertahan dalam dunia kerja.

\section{Pelatihan Soft Skills}

Berbagai cara yang dapat dilakukan untuk meningkatkan soft skills dan salah satunya adalah dengan pelatihan. Perusahaan atau organisasi dapat melakukan fungsinya dengan baik, apabila menerapkan tugas dan kewajiban secara efektif dan efisien. Dimana perkembangan bisnis dan persaingan antar organisasi dewasa ini bergerak dengan cepat dan dinamis. Dengan kondisi seperti ini maka menuntut sebuah organisasi untuk dapat bersikap lebih tanggap dalam melakukan pengembangan terhadap sumber daya manusianya.Dalam menjawab tantangan tersebut, maka sudah banyak organisasi yang melakukan tindakan dalam rangka peningkatan kinerja anggota organisasi melalui pelatihanpelatihan yang diselenggarakan. Pelatihan-pelatihan yang diselenggarakan diharapkan mampu berhasil sesuai dengan yang diharapkan. Dimana menurut Adiyasa (2011:3) cara lain yang dapat dilakukan untuk mempelajari, membentuk, dan meningkatkan soft skills adalah melalui pelatihan.

Sedangkan menurut Sailah (2008:2) soft skills merupakan Personal and interpersonal behaviors that develop and maximaize human performance. Dimana dalam hal ini bahwa soft skills adalah perilaku individu dan interpersonal yang dapat mengembangkan dan memaksimalkan kinerja. Sehingga dijelaskan lebih lanjut bahwa soft skills terbagi menjadi dua bagian, yakni intrapersonal skills dan interpersonal skills. Intrapersonal skills adalah keterampilan dalam diri seseorang untuk mengatur diri sendirinya, sedangkan Interpersonal skills adalah keterampilan seseorang yang dibutuhkan dalam melakukan hubungan dengan orang lain.

Ditambahkan pula, bahwa terdapat rincian dari masing-masing keterampilan tersebut, dimana intrapersonal skills terdiri atas: 1) Proses berpikir kreatif; 2) Mengelola stress; 3) Menetapkan tujuan, dan untuk interpersonal skillsyaitu: 1) Kemampuan komunikasi; 2) kemampuan negosiasi: 3) Kemampuan presentasi; 4) Kemampuan public speaking.

Kualitas organisasi sangat bergantung kepada kualitas sumber daya manusia organisasi tersebut, dimana mereka harus dapat memperkerjakan para karyawan yang berkulitas, agar tujuan organisasi dapat tercapai dengan baik. Kebutuhan akan sumber daya manusia semakin dirasa penting karena dalam menghadapi tantangan-tantangan serta daya kompetisi yang semakin tinggi, dan agar perusahaan mampu bersaing dengan ketat, maka banyak perusahaan yang memasukkan pelatihan sebagai bagian dari strategi utama perusahaan. Dimana menempatkan pelatihan sebagai wilayah fungsional yang 
paling penting. Karena diharapkan setelah mengikuti pelatihan karyawan mampu meningkatkan kualitas dan produktivitas kerjanya.

Pelatihan menurut Kaswan (2011:2) adalah proses meningkatkan pengetahuan dan keterampilan karyawan. Dikatakan bahwa kemampuan yang terdiri dari pengetahuan dan keterampilan tersebut merupakan kemampuan dasar yang harus dimiliki oleh karyawan agar dapat bekerja sesuai dengan pekerjaannya.Hal tersebut dipertegas dengan pengertian pelatihan menurut Suryana (2006:1) bahwa pelatihan sebagai aktifitas formal dan informal yang memberikan kontribusi pada perbaikan dan peningkatan pengetahuan, keterampilan dan sikap karyawan.Dimana pelatihan juga dapat meliputi pengubahan sikap sehingga karyawan dapat melakukan pekerjaannya lebih efektif.Sehingga pengetahuan dan keterampilan merupakan salah satu dasar karakteristik yang harus dimiliki oleh setiap karyawan untuk dapat melaksanakan pekerjaan-pekerjaannya dengan efektif dan efisien. Hal senada dijelaskan oleh Noe (2010:5):

Training refers to a planned effort by a company to facilitate employees' learning of job related competencies. These competencies include knowledge, skills, or behaviors that are critical for successful job performance, by Noe(2010:5).

Artinya bahwa pelatihan adalah upaya yang direncanakan untuk mempermudah pembelajaran para karyawan tentang kompetensi-kompetensi yang berkaitan dengan pekerjaan.Kompetensi-kompetensi tersebut meliputi pengetahuan, keterampilan atau perilaku yang sangat penting untuk keberhasilan kinerja pekerjaan.

Dimana sasaran pelatihan bagi para karyawan adalah menguasai pengetahuan, keterampilan dan perilaku yang ditekankan pada program-program pelatihan serta menerapkannya ke dalam aktivitas sehari-hari. Sehingga dapat mencapai keunggulan bersaing dan memandang sebuah pelatihan sebagai cara untuk menciptakan modal intelektual.

Usaha yang dilakukan perusahaan tersebut dalam rangka untuk mewujudkan tujuan perusahaan dan dapat mampu bersaing dengan ketat, sehingga dapat mewujudkan karyawan yang berkualitas dan memiliki kompetensi yang baik.

Hal ini lebih dipertegas kembali pengertian pelatihan menurut Bernardin yang dikutip oleh Sudarmanto (2009:2) adalah segala kegiatan untuk meningkatkan kinerja individu/ pegawai sesuai dengan pekerjaan atau jabatan yang dipegangnya dengan tugas saat ini.Dalam pandangan Bernardin tersebut, bahwa untuk meningkatkan kinerja karyawan yang sesuai dengan pekerjaannya saat ini, dapat dilakukan dengan pelatihan, sehingga dapat memperoleh karyawan dengan kinerja yang berkualitas. Hal ini dilakukan untuk mencapai kinerja organisasi yang optimal dengan memaksimalkan kualitas sumber daya manusia.

Dengan demikian, berdasarkan pengertian pelatihan di atas dapat disimpulkan bahwa pelatihan adalah proses kegiatan pengembangan sumber daya manusia yang bersifat formal maupun informal untuk meningkatkan pengetahuan, keterampilan dan sikap seseorang dalam mencapai tujuan yang diinginkan.

\section{Karakteristik Soft Skills}

Adapun komponen-komponen pelatihan menurut Mangkunegara (2008) adalah sebagai berikut:

1. Tujuan dan sasaran pelatihan harus jelas dan dapat diukur.

2. Para pelatih harus ahlinya yang berkualifikasi memadai (profesional).

3. Materi pelatihan harus disesuaikan dengan tujuan yang hendak dicapai. 
4. Metode pelatihan harus disesuaikan dengan tingkat kemampuan pegawai yang menjadi peserta.

5. Peserta pelatihan harus memenuhi persyaratan yang ditentukan.

Proses keberhasilan suatu perusahaan terdiri dari beberapa faktor yang mempengaruhi, dan salah satu faktor utama yang sangat mempengaruhi adalah sumber daya manusia. Sehingga sumber daya manusia yang berkualitas sangat diharapkan untuk dapat memperoleh kinerja yang unggul.Memperoleh kinerja yang unggul dapat dilakukan salah satunya dengan pelaksanaan pelatihan, dimana menurut Kaswan (2011:55) pelatihan yang efektif adalah pelatihan yang dapat meningkatkan kinerja, sehingga dapat dengan jelas disebutkan bahwa pelatihan mampu memberikan pengaruh terhadap kinerja karyawan.Pelatihan yang dirancang dengan analisis kebutuhan pelatihan, penggunaan metode pelatihan, perencanaan materi pelatihan dan evaluasi pelatihan.Hal tersebut bertujuan untuk membantu karyawan dalam mencapai kinerja unggulnya.

Dalam pengujian penelitian yang dilakukan oleh Rifa Ristanti (2009) bahwa hasil hipotesis menunjukkan pelatihan berpengaruh positif terhadap kinerja karyawan, dimana besar pengaruhnya adalah sebesar 14,1\%. Dengan pelaksanaan pelatihan yang diuji sudah mampu mampu meningkatkan kinerja karyawan.

Dalam sebuah jurnal mengenai hubungan pelatihan dengan kinerja yang dikemukakan oleh Abd Hair Awang, Rahmah Ismail dan Zulridah Mohd Noor pada tahun 2010 yang berjudul "Training impact on employess's job performance: a selfevaluation", dijelaskan bahwa hasil penelitiannya menunjukan pelatihan berpengaruh secara signifikan terhadap kinerja, dimana pelatihan tersebut mampu meningkatkan pengetahuan, keterampilan dan sikap karyawan dengan positif.

Dengan demikian setelah beberapa penjelasan di atas mengenai pelatihan soft skills, maka yang menjadi dimensi dan indikator dalam penelitian ini adalah: (1) intrapersonal skills, yaitu: a) proses berpikir kreatif; b) Mengelola stress; c) Menetapkan tujuan; (2) interpersonal skills, yang terdiri atas: a) Kemampuan komunikasi; b) kemampuan negosiasi; c) Kemampuan presentasi; d) Kemampuan public speaking.

\section{Digital Entrepreneur}

Pertama kali munculnya kewirausahaan terjadi mulai tahun 1930an di Jepang, sementara itu di Amerika Serikat menurut Scuotto (2013) mulai tahun 1970an dan mulai dari perkembangan di Amertika Serikat itulah terdapat berbagai penelitian yang membahas tentang kewirausahaan.Hal tersebut menjadi sangat menarik karena hasil-hasil dari penelitian dibuat kedalam modul untuk kalangan siswa-siswi di sekolah yang akhirnya dapat diimplementasikan oleh mereka.

Menariknya hasil dari modul yang diadopsi bertujuan untuk meningkatkan keterampilan para siswa-siswi, melalui cara menulis business plan, membahas studi kasus, pembelajaran, dan mendatangkan wirausaha dari luar. Ini tentunya dapat mengembangkan dan meningkatkan keinginan mereka dalam beriwirausaha karena sudah diterapkan sejak dini dengan pendekatan yang dapat diterima oleh mereka.

Saat ini sedang berkembang istilah digital entrepreneur, dijelaskan menurut Li Wenjie, et.al (2017), (Davidson, 2010) adalah sebuah fenomena yang beragam yang memiliki tiga tipe yakni bisnis kewirausahaan, pengetahuan kewirausahaan, dan institusi kewirausahaan. Ketiga tipe kewirausahaan tersebut yang mampu membentuk sebuah sistem yang terintegrasi dengan adanya sebuah digital sebagai penghubung. Hal tersebut diperkuat oleh penjelasan dari Sussan (2017) bahwa pada dasarnya pembentukan sebuah 
digital entrepreneur dari sistem digital dan kewirausahaan secara terpisah yang memiliki fokus masing-masing, dimana dipertegas kembali bahwa kewirausahaan dapat mengeluarkan sebuah inovasi baik berbasis teknologi maupun non teknologi.

\section{METODE KEGIATAN}

Metode kegiatan yang digunakan pada kegiatan ini diharapkan dapat memberikan kemudahan kepada peserta kegiatan. Dalam kegiatan ini, metode yang digunakan adalah metode survey dengan teknik observasi, wawancara, dan penyebaran kuesioner, adapun metode pembelajarannya melalui penjelasan dan diskusi, Tanya jawab, berbagi pengalaman, studi kasus. Pada metode penjelasan, setiap instruktur menyampaikan materi terkait dan setiap instruktur direncanakan akan membuat power point slide dan modul ringkas kegiatan yang akan dibagikan kepada peserta kegiatan. Adapun alat bantu kegiatan seperti LCD proyektor juga direncanakan akan digunakan sehingga peserta lebih mudah memahami materi kegiatan. Namun karena sedang pandemic maka kegiatan dilakukan melalui zoom meet.

\section{HASIL DAN PEMBAHASAN}

\section{Profil Responden}

Responden dalam kegiatan edukasi dan pelatihan ini berjumlah 33 orang pada kalangan masyarakat yang memiliki UMKM, adapun rincian dari profil responden ini adalah sebagai berikut:

Berdasarkan hasil dari profil responden di atas serta hasil dari perkembangan pengetahuan responden selama kegiatan edukasi dan pelatihan berlangsung, maka dapat diketahui bahwa $63 \%$ berjenis kelamin perempuan dan $37 \%$ berjenis kelamin laki-laki, rata-rata usia mereka adalah 19 - 30 tahun, 68\% tingkat pendidikan terakhir mereka adalah SMA. Adapun jenis usaha yang dikelola oleh para responden, mayoritas adalah usaha jenis makanan dan kuliner sebanyak 30\%. Pendapatan yang diperoleh para responden rata-rata $\mathrm{Rp} 500.000$ - Rp 1.000 .000 sebanyak $61 \%$. Kemudian, media sosial yang paling sering digunakan adalah Facebook 50\% dan Whatsapp 42\% sisanya adalah line, twitter dan instagram, sementara itu penggunaan media sosial tersebut paling sering digunakan untuk menambah komunitas $42 \%$ dan sisanya adalah untuk membagi informasi ke teman-teman, menambah teman, selfie dan narsis. Selanjutnya pernyataan tentang pengetahuan para responden tentang digital entrepreneur $100 \%$ responden menjawab tidak. Pernyataan berikutnya adalah ketertarikan responden untuk mengaplikasikan usaha melalui digital, seluruh responden menjawab $100 \%$ ya.

\section{Analisis Teoretis}

Pelaksanaan pelatihan ini bagi masyarakat UMKM di wilayah DKI Jakarta dan sekitarnya ini tidak dapat dicapai jika tidak dapat dukungan dari berbagai pihak, terutama para pegawai atau staff yang bekerja di kelurahan yang mana telah membantu mensosialisasikan kegiatan ini kepada para masyarakat sekitar pelaku UMKM. Adapun cara yang digunakan adalah dengan melakukan penyampaian materi kepada para peserta. Dan agar materi dapat dipahami dengan baik maka tim memilih metode pemberian materi dilanjutkan sesi tanya jawab dan sharing.

Setelah peserta mendapatkan edukasi, tentunya para peserta harus mampu meningkatkan pengetahuannya akan kebermanfaatan media sosial dalam menumbuhkan 
kewirausahaan sejak dini. Hal ini sangat diharapkan supaya kedepannya bermunculan generasi muda yang mandiri, kreatif dan bijak dalam menggunakan media social dalam berwirausaha.

Dari beberapa pertanyaan kuesioner di atas tersebut, hal yang menjadi perhatian adalah terkait ketidak tahuan mereka tentang apa itu digital entrepreneur padahal saat ini penting bagi mereka untuk mengetahui dan mengaplikasikan digital entrepreneur.

Jenis usaha yang beragam juga menjadi penentu bagi keberlangsungan sector UMKM, terdapat positifisme terkait hal itu, dimana daya saing semakin meningkat dan minat terhadap UMKM juga semakin tinggi. Hal ini menandakan bahwa UMKM salah satu sektor yang dapat memberikan harapan besar bagi pertumbuhan ekonomi Indonesia yang mampu memberikan kesejahteraan bagi para pelaku serta mampu mengurangi angka pengangguran.

\section{DAFTAR PUSTAKA}

Lasi, Heiner, Peter Fettke. (2014). Industry 4.0".Journal of Business and Information Systems Engineering. Vol. 4.

Li, Wenjie, Wenyu Du, Jiamin Yin. (2017). Digital Entrepreneurship Ecosystem as a New Form of Organizing: the Case of Zhongguancun. Journal of Business Research in China.

Mazali, Tatiana. (2017). From Industry 4.0 to Society 4.0, there and Back. Journal of Business and Information Systems Engineering.

Myers K, Karen, Kamyab Sadaghiani. (2010). Millennials in the workplace: A Communication Perspective on Millennials' Organizational Relationships and Performance. Journal of Business Psychology.

Ozcelik, Gaye, (2015). Engagement and Retention of the Millennial Generation in the Workplace through Internal Branding. International Journal of Business and Management. Vol. 10 No. 3

Scuotto, Veronica, Massimo Morellato. (2013). Entrepreneurial Knowledge and Digital Competence: Keys for a Success of Student Entrepreneurship. Journal Knowledge Economic.

Sussan, Fiona, Zoltan J Acs. (2017). The Digital Entrepreneurial Ecosystem. Journal of Small Business Economics.

S.W.Ng, Eddy, Linda Schweitzer, Sean T.Lyons. (2010). New Generation, Great Expectations: A Field Study of the Millennial Generation. Journal of Business Psychology.

Zheng, Pai, et al. (2018). Smart Manufacturing Systems for Industry 4.0: Conceptual Framework, Scenarios, and Future Perspectives. Frontiers of Mechanical Engineering Journal. 